\begin{tabular}{|l|l|l||}
\hline \multicolumn{2}{|c|}{ PublisherInfo } \\
\hline \hline PublisherName & $:$ & BioMed Central \\
\hline \hline PublisherLocation & $:$ & London \\
\hline \hline PublisherImprintName & $:$ & BioMed Central \\
\hline \hline
\end{tabular}

\title{
'Flesh-eater' genome
}

\begin{tabular}{|l|l|l||}
\hline \multicolumn{2}{|c|}{ ArticleInfo } \\
\hline \hline ArticleID & $:$ & 4380 \\
\hline \hline ArticleDOI & $:$ & $10.1186 /$ gb-spotlight-20020118-01 \\
\hline \hline ArticleCitationID & $:$ & spotlight-20020118-01 \\
\hline \hline ArticleSequenceNumber & $:$ & 46 \\
\hline \hline ArticleCategory & $:$ & Research news \\
\hline \hline ArticleFirstPage & $:$ & 1 \\
\hline \hline ArticleLastPage & $:$ & 2 \\
\hline \hline & & RegistrationDate : 2002-01-18 \\
ArticleHistory & $:$ & OnlineDate \\
\hline \hline ArticleCopyright & $:$ & BioMed Central Ltd2002-01-18 \\
\hline \hline ArticleGrants & $:$ & \\
\hline \hline ArticleContext & $:$ & 130593311 \\
\hline \hline
\end{tabular}




\section{Jonathan B Weitzman}

Email: jonathanweitzman@hotmail.com

Clostridium perfringens is the most widely distributed pathogen, and is a cause of gas gangrene, necrotic enteritis and diarrhoea. In the January 22 Proceedings of the National Academy of Sciences, Shumizu et al. report the genome sequence of $C$. perfringens strain 13, the first Gram-positive anaerobic pathogen to be completely sequenced (Proc Natl Acad Sci USA 2002, 99:996-1001). The genome is just over $3 \mathrm{Mb}$ long, with a low $\mathrm{G}+\mathrm{C}$ content (28.6\%). They found 2660 predicted proteins, half of which could be assigned a possible function. Shumizu et al. compared the $C$. perfringens genome with that of C. acetobutylicum to get clues about gene function. They found genes encoding enzymes for anaerobic fermentation, glycolysis and glycogen metabolism, but none for the tricarboxylic acid cycle; they also found only a partial set of enzymes for amino-acid synthesis. Shumizu et al. identified several virulenceassociated genes including putative hemolysins, toxins, and adhesins.

\section{References}

1. Clostridium perfringens toxins (type A, B, C, D, E).

2. Proceedings of the National Academy of Sciences, [http://www.pnas.org]

3. Clostridium perfringens strain 13, [http://w3.grt.kyushu-u.ac.jp/CPE/]

4. Genome sequence and comparative analysis of the solvent-producing bacterium Clostridium acetobutylicum. 